\title{
Ultrathin CVD Cu Seed Layer Formation Using Copper Oxynitride Deposition and Room Temperature Remote Hydrogen Plasma Reduction
}

\section{Citation}

Kim, Hoon, Harish B. Bhandari, Sheng Xu, Roy G. Gordon. 2008. Ultrathin CVD Cu seed layer formation using copper oxynitride deposition and room temperature remote hydrogen plasma reduction. Journal of The Electrochemical Society 155, no. 7: H496-H503.

\section{Published Version}

http://dx.doi.org/10.1149/1.2912326

\section{Permanent link}

http://nrs.harvard.edu/urn-3:HUL.InstRepos:3347571

\section{Terms of Use}

This article was downloaded from Harvard University's DASH repository, and is made available under the terms and conditions applicable to Other Posted Material, as set forth at http:// nrs.harvard.edu/urn-3:HUL.InstRepos:dash.current.terms-of-use\#LAA

\section{Share Your Story}

The Harvard community has made this article openly available.

Please share how this access benefits you. Submit a story.

\section{Accessibility}




\title{
(4hS) Ultrathin CVD Cu Seed Layer Formation Using Copper
Oxynitride Deposition and Room Temperature
Remote Hydrogen Plasma Reduction
}

\author{
Hoon Kim, Harish B. Bhandari, Sheng Xu, and Roy G. Gordon *,z \\ Department of Chemistry and Chemical Biology, Harvard University, Cambridge, \\ Massachusetts 02138, USA
}

\begin{abstract}
$\mathrm{Cu}$ seed layers for future interconnects must have conformal step coverage, smooth surface morphology, and strong adhesion. Conformal deposition had been achieved by chemical vapor deposition (CVD), but CVD Cu films have rough surfaces and poor adhesion. In this paper, conformal, smooth, adherent, continuous, and thin $(<9 \mathrm{~nm}) \mathrm{Cu}$ films were made by CVD. CuON was deposited from a Cu-amidinate precursor, $\mathrm{H}_{2} \mathrm{O}$, and $\mathrm{NH}_{3}$ at $140-180^{\circ} \mathrm{C}$ on Ru. Crystallites in the deposited film have either a $\mathrm{Cu}_{2} \mathrm{O}$ or $\mathrm{Cu}_{3} \mathrm{~N}$ structure depending on the ratio of $\mathrm{H}_{2} \mathrm{O}$ to $\mathrm{NH}_{3}$. As-deposited $\mathrm{CuON}$ films have a smooth surface morphology $[\sim 0.5 \mathrm{~nm}$ root-mean-square (rms) roughness $]$ and are highly conformal (>95\% step coverage in 40:1 aspect ratio holes). The $\mathrm{CuON}$ films were then reduced with remote hydrogen plasma near room temperature to minimize agglomeration of the thin $\mathrm{Cu}$ films during reduction. After reduction, $\mathrm{CuON}$ films having a $\mathrm{Cu}_{2} \mathrm{O}$ crystal structure showed a higher density $\mathrm{Cu}$ film (95\%) than those having a $\mathrm{Cu}_{3} \mathrm{~N}$ crystal structure $(84 \%)$. Both reduced $\mathrm{Cu}$ films had a smooth morphology ( $\sim \mathrm{nm}$ rms roughness). Thus, deposition of a $\mathrm{CuON}$ film having a $\mathrm{Cu}_{2} \mathrm{O}$ crystal structure and then reduction with remote hydrogen plasma can make $\mathrm{Cu}$ layers that can serve as seed layers of future $\mathrm{Cu}$ interconnects.
\end{abstract}

(C) 2008 The Electrochemical Society. [DOI: 10.1149/1.2912326] All rights reserved.

Manuscript submitted January 18, 2008; revised manuscript received February 15, 2008. Available electronically May 5, 2008.

$\mathrm{Cu}$ is used as the interconnect material for ultralarge-scale integrated circuits due to its low resistivity and excellent stability against stress migration and electromigration. $\mathrm{Cu}$ is filled by electrochemical deposition (ECD), which has the merits of a low process temperature, a high deposition rate, a cost effective process, and a complete via filling capability. This ECD method requires a thin $\mathrm{Cu}$ seed layer as an electrode. In current technology, the $\mathrm{Cu}$ seed layer is deposited by sputtering on Ta over a TaN diffusion barrier. However, beyond the $45 \mathrm{~nm}$ generation, sputtering cannot cover the sidewalls of vias and trenches uniformly due to its poor step coverage, which results in void formation during ECD and a reduced durability of interconnects. ${ }^{1}$ Thus, a conformal deposition method for $\mathrm{Cu}$ seed layer deposition is required. ${ }^{2}$ Chemical vapor deposition (CVD) and atomic layer deposition (ALD) are well-known methods of conformal $\mathrm{Cu}$ seed layer deposition. ${ }^{3-9}$ From the viewpoint of productivity, CVD is the most promising candidate for $\mathrm{Cu}$ seed layer deposition. For the $32 \mathrm{~nm}$ generation, considering the metal linewidth $(\sim 32 \mathrm{~nm})$ and the thickness of the barrier/cladding (2.4 nm), a conformal, smooth, adherent, and continuous CVD Cu seed layer less than $10 \mathrm{~nm}$ thick is required. ${ }^{10}$

To deposit $10 \mathrm{~nm}$ of continuous $\mathrm{CVD} \mathrm{Cu}$, new underlayers should be considered because $\mathrm{Ta} / \mathrm{TaN}$ underlayers cause a rough morphology and poor adhesion. ${ }^{4,5} \mathrm{Ru}$ is an air-stable metal with a low resistivity and no solubility in $\mathrm{Cu}$, and it does not form any intermetallic compounds with $\mathrm{Cu}$. ${ }^{11}$ More importantly, $\mathrm{Ru}$ has a strong adhesion to CVD $\mathrm{Cu}$ compared with Ta or TaN. ${ }^{6,7,12,13} \mathrm{Al}-$ though $\mathrm{Cu}$ has a fairly high wettability on $\mathrm{Ru}, 10 \mathrm{~nm}$ of continuous $\mathrm{CVD} \mathrm{Cu}$ seed layer cannot be deposited on $\mathrm{Ru}$, because metallic $\mathrm{Cu}$ made by CVD has typical three-dimensional (3D) island growth and requires a thickness of at least $20 \mathrm{~nm}$ to form a continuous layer. ${ }^{5}$

To deposit a thin $(<10 \mathrm{~nm})$, smooth, and continuous CVD seed layer, a different approach is required. $\mathrm{Cu}$ compounds, such as $\mathrm{Cu}$ oxide or nitride, have a better wettability than metallic $\mathrm{Cu}$, which results in a higher nucleation density, and continuous thin layers with a smoother and more continuous morphology than metallic $\mathrm{Cu}$. There is a report of $\mathrm{CVD} \mathrm{Cu}_{2} \mathrm{O}$ deposition for seed layer application. ${ }^{14}$ However, the reduction process temperature is $275^{\circ} \mathrm{C}$, which is too high to form a thin, continuous, and smooth seed layer for future $\mathrm{Cu}$ interconnect processing. The Ta underlayer used for that experiment is oxidized during oxide deposition, which de-

* Electrochemical Society Active Member

z E-mail: gordon@chemistry.harvard.edu creases the adhesion strength of $\mathrm{Cu}$ to $\mathrm{Ta}$ and increases the contact resistance. Thus, there is need for a new precursor having a low deposition temperature and a new underlayer that can be easily reduced. Deposition of $\mathrm{Cu}_{3} \mathrm{~N}$ can also be a good candidate. ALD $\mathrm{Cu}_{3} \mathrm{~N}$ deposition and reduction shows the possibility of thin seed layer fabrication, ${ }^{15,16}$ but ALD is too slow for large-scale production. The reported CVD process for $\mathrm{Cu}_{3} \mathrm{~N}$ required a high deposition temperature $\left(400^{\circ} \mathrm{C}\right)$ and it did not mention the morphology, which is most important in this application. ${ }^{17}$

Reduction of a deposited $\mathrm{Cu}_{2} \mathrm{O}$ or $\mathrm{Cu}_{3} \mathrm{~N}$ film to copper metal must be done at a low enough temperature to avoid agglomeration of the $\mathrm{Cu}$. The reduction of a $\mathrm{Cu}$ oxide or nitride at too high a temperature produces rough and discontinuous $\mathrm{Cu}$ films. ${ }^{14,15,18,19}$ Thus, the reduction of $\mathrm{Cu}$ compounds should be conducted at as low a temperature as possible to maintain the smooth and continuous morphology of as-deposited $\mathrm{Cu}$ compound films.

In this study, we deposited $\mathrm{Cu}$ oxide, nitride, and oxynitride $(\mathrm{CuON})$ using $\mathrm{CVD}$, and then these compounds were compared from the viewpoint of morphology and film density before and after reduction to copper metal. A $\mathrm{Cu}$ amidinate, $\left(N, N^{\prime}\right.$-di-sec-butylacetamidinato)copper(I) dimer (abbreviated $\left.\left[\mathrm{Cu}\left({ }^{\mathrm{s}} \mathrm{Bu}-\mathrm{Me}-\mathrm{amd}\right)\right]_{2}\right)$, was used to decrease the deposition temperature. This precursor's reactivity at a low substrate temperature has been reported under ALD conditions. ${ }^{9,15} \mathrm{Cu}$ oxide, $\mathrm{Cu}$ nitride, and $\mathrm{CuON}$ are formed by using $\mathrm{Cu}$ amidinate with $\mathrm{H}_{2} \mathrm{O}$ and $\mathrm{NH}_{3}$ as reactant gases.

The $\mathrm{Cu}$ compound films were then reduced by $\mathrm{H}_{2}$ remote-plasma treatment because atomic hydrogen is one of the strongest reducing agents, which can enable room temperature reduction and minimize agglomeration of the copper. ${ }^{19,20} \mathrm{Cu}_{2} \mathrm{O}$ reacts with atomic hydrogen to form pure $\mathrm{Cu}$ and water by the following reaction

$$
\mathrm{Cu}_{2} \mathrm{O}+2 \mathrm{H} \rightarrow 2 \mathrm{Cu}+\mathrm{H}_{2} \mathrm{O}
$$

Provided that no kinetic limitations exist, this reaction will occur because the Gibbs energy change of this reaction is $-118.3 \mathrm{kcal} / \mathrm{mol}$ at $25^{\circ} \mathrm{C}$. ${ }^{21}$ Thus, $\mathrm{Cu}_{2} \mathrm{O}$ might be reduced with atomic hydrogen even at room temperature.

In this work, we found that the crystal structure of as-deposited $\mathrm{CuON}$ films differed depending upon the ratios of $\mathrm{H}_{2} \mathrm{O}$ to $\mathrm{NH}_{3}$ during depositions. A high $\mathrm{H}_{2} \mathrm{O}$ ratio makes films with a $\mathrm{Cu}_{2} \mathrm{O}$ crystal structure, while a high $\mathrm{NH}_{3}$ ratio makes a $\mathrm{Cu}_{3} \mathrm{~N}$ crystal structure. Even though a film has a $\mathrm{Cu}_{2} \mathrm{O}$ or $\mathrm{Cu}_{3} \mathrm{~N}$ crystal structure, both oxygen and nitrogen are incorporated in the film when a mixture of $\mathrm{H}_{2} \mathrm{O}$ and $\mathrm{NH}_{3}$ is used as a reactant gas during deposition. However, 
the overall deposition rate of the film is mainly determined by the $\mathrm{H}_{2} \mathrm{O}$ flow rate. $\mathrm{CuON}$ film shows a smooth surface morphology [root-mean-square $(\mathrm{rms})$ roughness $<1 \mathrm{~nm}$ ]. CuON films having $\mathrm{Cu}_{2} \mathrm{O}$ structure have higher density than films having $\mathrm{Cu}_{3} \mathrm{~N}$ structure. After 1 min reduction with $\mathrm{H}_{2}$ remote plasma at room temperature, both films are fully reduced to $\mathrm{Cu}$ metal that has smooth morphology (rms roughness $\sim 1 \mathrm{~nm}$ ) and low resistivity $(12 \mu \Omega \mathrm{cm}$ at $9 \mathrm{~nm}$ thickness). $\mathrm{CVD} \mathrm{CuON}$ films having $\mathrm{Cu}_{2} \mathrm{O}$ structure form $\mathrm{Cu}$ with higher density after reduction than $\mathrm{CuON}$ films having $\mathrm{Cu}_{3} \mathrm{~N}$ structure do. Room temperature remote hydrogen plasma reduction is the best method to maintain smooth surface morphology. Thus, this process can be a promising candidate of thin CVD Cu seed layer deposition for future $\mathrm{Cu}$ interconnects.

\section{Experimental}

The deposition of $\mathrm{CuON}$ was done in a tube-furnace type reactor which has $36 \mathrm{~mm}$ inner diameter (i.d.). Copper (I) $N, N^{\prime}$-di-sec-butylacetamidinate $\left(\left[\mathrm{Cu}\left({ }^{\mathrm{s}} \mathrm{Bu}-\mathrm{Me} \text {-amd }\right)\right]_{2}\right)$ was used as a $\mathrm{Cu}$ precursor, which was delivered by bubbling with $40 \mathrm{sccm}$ of $\mathrm{N}_{2}$ carrier gas. The bubbler temperature was $130^{\circ} \mathrm{C}$, which maintained the $\mathrm{Cu}$ precursor as a liquid phase because its melting point is $77^{\circ} \mathrm{C}$. All the gas lines, bubbler, and valves were located in an oven which maintained a good temperature uniformity. $\mathrm{H}_{2} \mathrm{O}$ was used as an oxygen source, which was evaporated from a reservoir at room temperature without any carrier gas. The flow rate of water vapor was controlled by a needle valve that was calibrated by comparing with the pressure increase of the chamber by a measured $\mathrm{N}_{2}$ flow rate. $\mathrm{NH}_{3}$ was supplied as a nitrogen source whose flow rate was controlled by a mass flow controller. The total flow rate of reactant gases $\left(\mathrm{H}_{2} \mathrm{O}\right.$ and $\left.\mathrm{NH}_{3}\right)$ was maintained at $40 \mathrm{sccm}$, and the ratio of $\mathrm{H}_{2} \mathrm{O}$ to $\mathrm{NH}_{3}$ was set to the values $40: 0,30: 10,20: 20,10: 30$, or $0: 40$. The reaction gases were mixed with $\mathrm{Cu}$ precursor vapor in a small ( $5 \mathrm{~mm}$ i.d.) tube just prior to entering the reactor tube $(36 \mathrm{~mm}$ i.d.) to ensure thorough mixing. The films were deposited at substrate temperatures from 140 to $220^{\circ} \mathrm{C}$ under a total chamber pressure of 8 Torr. The films were reduced with $\mathrm{H}_{2}$ remote plasma, which heated the substrates from room temperature to temperatures as high as $50^{\circ} \mathrm{C}$. A toroidal plasma generator (ASTRON I type AX7670, MKS) was supplied with $180 \mathrm{sccm}$ of Ar for plasma ignition and $200 \mathrm{sccm}$ of $\mathrm{H}_{2}$, which upon dissociative excitation acted as a reducing agent. The reduction time was varied from 30 to $180 \mathrm{~s}$. A Si wafer with a $100 \mathrm{~nm}$ thermal oxide was used as the substrate. Ru was deposited by sputtering to a $20 \mathrm{~nm}$ thickness and exposed to the atmosphere prior to CVD.

The surface morphologies of the as-deposited $\mathrm{CuON}$ and reduced films were evaluated by an atomic force microscope (AFM, Asylum MFP-3D AFM). The thickness and composition of the deposited films were measured using $2 \mathrm{MeV} \mathrm{He} \mathrm{H}^{+}$Rutherford backscattering spectroscopy (RBS). The physical thicknesses of $\mathrm{CuON}$ and reduced $\mathrm{Cu}$ films were measured by AFM after making stripe patterns by photolithography and etching in dilute nitric acid. $\mathrm{CuON}$ and $\mathrm{Cu}$ films were etched with nitric acid diluted by deionized water in a volume ratio 1 (acid): 40 (water) or 1:10, respectively. The resistivities of reduced $\mathrm{Cu}$ films were evaluated by a four-point probe (Miller Design \& Equipment FPP-5000). The phases of as-deposited $\mathrm{Cu}$ oxynitride and reduced films were evaluated by transmission electron microscopy (TEM) diffraction (JEOL JEL2010 TEM) using as a substrate a $50 \mathrm{~nm}$ thick $\mathrm{Si}_{3} \mathrm{~N}_{4}$ membrane TEM grid (Ted Pella, Inc., prod. no. 21500-10).

\section{Results and Discussion}

$\mathrm{Cu}$ oxynitride deposition with $\left[\mathrm{Cu}\left({ }^{\mathrm{s}} \mathrm{Bu}-\mathrm{Me} \text {-amd }\right)\right]_{2}, \mathrm{H}_{2} \mathrm{O}$, and $\mathrm{NH}_{3}$.- Temperature effect on $\mathrm{CuON}$ film deposition.- $\mathrm{CuON}$ was deposited from $\left[\mathrm{Cu}\left({ }^{\mathrm{s}} \mathrm{Bu}-\mathrm{Me}-\mathrm{amd}\right)\right]_{2}$ vapor and a mixture of $\mathrm{H}_{2} \mathrm{O}$ vapor and $\mathrm{NH}_{3}$ gas. Figure 1 shows the deposition rate of $\mathrm{Cu}$ oxynitride at different deposition temperatures. The ratio of $\mathrm{H}_{2} \mathrm{O}$ flow to $\mathrm{NH}_{3}$ flow was 30:10 in these depositions. The deposition rate increased with increasing deposition temperature, up to a value over

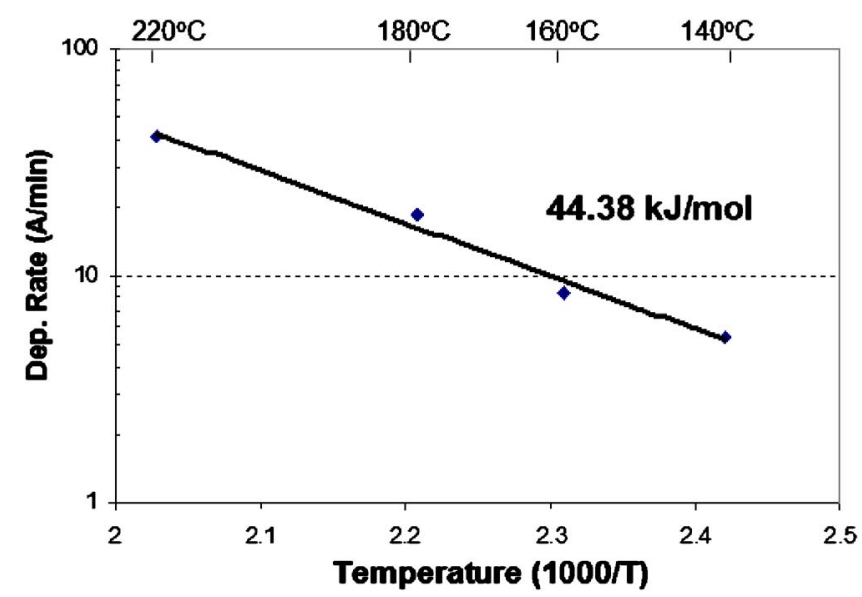

Figure 1. (Color online) Arrhenius plot of $\mathrm{CuON}$ deposition rate from $\left[\mathrm{Cu}\left({ }^{\mathrm{s}} \mathrm{Bu}-\mathrm{Me}-\mathrm{amd}\right)\right]_{2}$ vapor and a mixture of $30 \mathrm{sccm}$ of $\mathrm{H}_{2} \mathrm{O}$ and $10 \mathrm{sccm}$ of $\mathrm{NH}_{3}$.

$4 \mathrm{~nm} \min ^{-1}$. Over the range of temperature studied $\left(140-220^{\circ} \mathrm{C}\right)$, the deposition rate has an Arrhenius form, which means that the CVD reaction is kinetically controlled in that temperature range. The activation energy of this reaction was found to be $44 \mathrm{~kJ} / \mathrm{mol}$.

The morphology of $\mathrm{CuON}$ depends on the deposition temperature, as shown in Fig. 2 for films with thicknesses about $20 \mathrm{~nm}$. These films are all smooth, with a rms roughness $<1 \mathrm{~nm}$. The smoothest film was deposited at $160^{\circ} \mathrm{C}$, with a roughness of only $0.5 \mathrm{~nm}$, which is just slightly larger than the roughness of the Si substrate. The surface grain size of $\mathrm{CuON}$ is constant at about $20 \mathrm{~nm}$ up to a deposition temperature of $180^{\circ} \mathrm{C}$. At $220^{\circ} \mathrm{C}$, some large particles $400-600 \mathrm{~nm}$ in diameter were observed on the film surface, although the film still had a smooth surface morphology (rms roughness $1.04 \mathrm{~nm})$ and a fairly small grain size $(\sim 40 \mathrm{~nm})$. These particles seemed to be formed by gas-phase reaction at the highest temperature. Thus, $\mathrm{CuON}$ for a seed layer can be deposited over the temperature range from about $140-180^{\circ} \mathrm{C}$ from the viewpoint of surface morphology. This result is different from the temperature effect on morphology of $\mathrm{Cu}_{2} \mathrm{O}$ and $\mathrm{Cu}_{3} \mathrm{~N}$. The morphology of pure $\mathrm{Cu}$ compounds such as $\mathrm{Cu}_{2} \mathrm{O}$ and $\mathrm{Cu}_{3} \mathrm{~N}$ was very sensitive to deposition temperature. ${ }^{15,19} \mathrm{~A}$ deposition temperature only 30 or $40^{\circ} \mathrm{C}$ higher than the optimized condition always made films with a rough morphology in the deposition of pure $\mathrm{Cu}$ compounds. However, $\mathrm{CuON}$ is less affected by deposition temperature, so smooth $\mathrm{CuON}$ films are obtained over a wider process window than for $\mathrm{Cu}_{2} \mathrm{O}$ or $\mathrm{Cu}_{3} \mathrm{~N}$ films.

The composition of $\mathrm{CuON}$ deposited at different temperatures is shown in Fig. 3. The atomic percentages of $\mathrm{Cu}, \mathrm{O}$, and $\mathrm{N}$ are compared at 140,180 , and $220^{\circ} \mathrm{C}$ as measured by RBS for films deposited on amorphous carbon substrates. The composition does not change much over that temperature range, which means that $\mathrm{CuON}$ is a stable phase under these deposition conditions. Thus, $\mathrm{CuON}$ has a relatively wide process window in which to get a uniform composition and morphology because it is less sensitive to the deposition temperature. Pure $\mathrm{Cu}_{2} \mathrm{O}$ and $\mathrm{Cu}_{3} \mathrm{~N}$ showed a single phase and smooth morphology only in a narrower temperature range. ${ }^{15,19}$

The effect of $\mathrm{H}_{2} \mathrm{O}$ to $\mathrm{NH}_{3}$ ratio on $\mathrm{CuON}$ film deposition.- The deposition rate of $\mathrm{CuON}$ depends on the $\mathrm{H}_{2} \mathrm{O}$ to $\mathrm{NH}_{3}$ ratio at $140^{\circ} \mathrm{C}$ as shown in Fig. 4. The deposition rate is mainly determined by the $\mathrm{H}_{2} \mathrm{O}$ flow rate, showing that $\mathrm{H}_{2} \mathrm{O}$ is more reactive than $\mathrm{NH}_{3}$ with the $\mathrm{Cu}$ amidinate precursor. Without $\mathrm{H}_{2} \mathrm{O}$, no film was deposited at $140^{\circ} \mathrm{C}$, which shows that the $\mathrm{Cu}$ precursor and $\mathrm{NH}_{3}$ alone cannot nucleate a $\mathrm{Cu}_{3} \mathrm{~N}$ film at $140^{\circ} \mathrm{C}$. At substrate temperatures over $200^{\circ} \mathrm{C}$, some $\mathrm{Cu}_{3} \mathrm{~N}$ film was deposited, but it has a very rough morphology. Thus, $\mathrm{CuON}$ film was investigated due to its smoother morphology and higher deposition rate. 
(a) $140^{\circ} \mathrm{C}$, RMS: $0.64 \mathrm{~nm}$

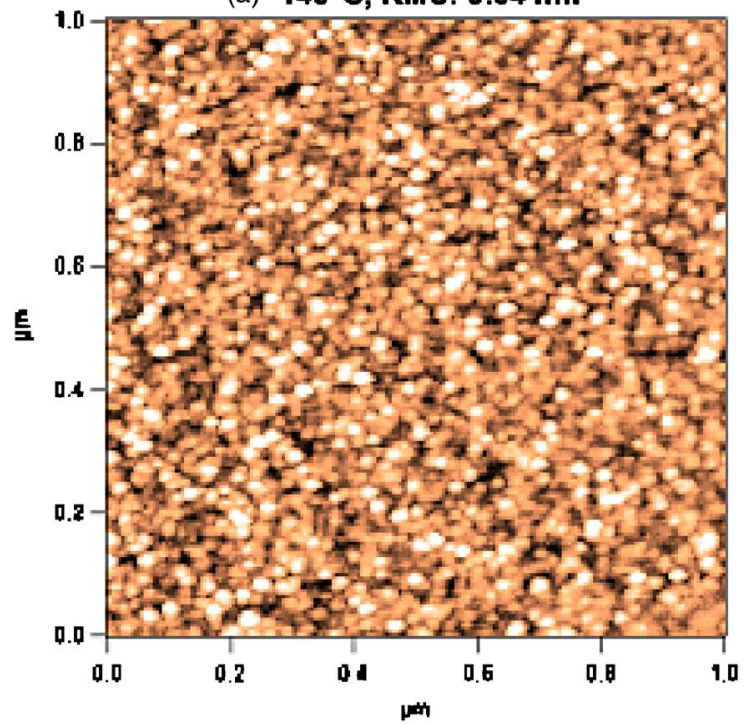

(c) $180^{\circ} \mathrm{C}$, RMS: $0.72 \mathrm{~nm}$

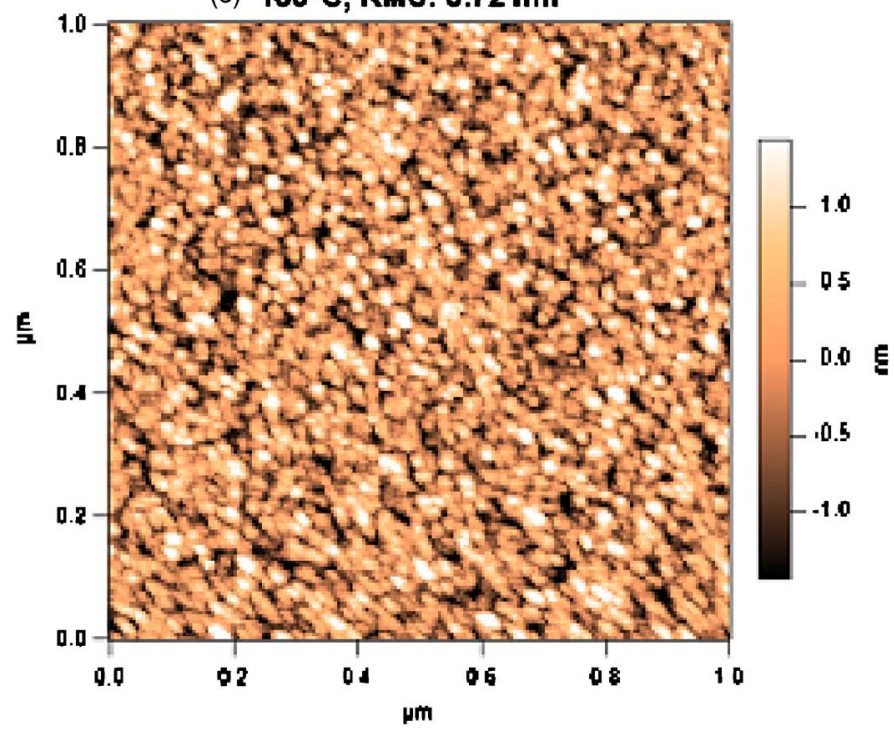

(b) $160^{\circ} \mathrm{C}$, RMS: $0.54 \mathrm{~nm}$

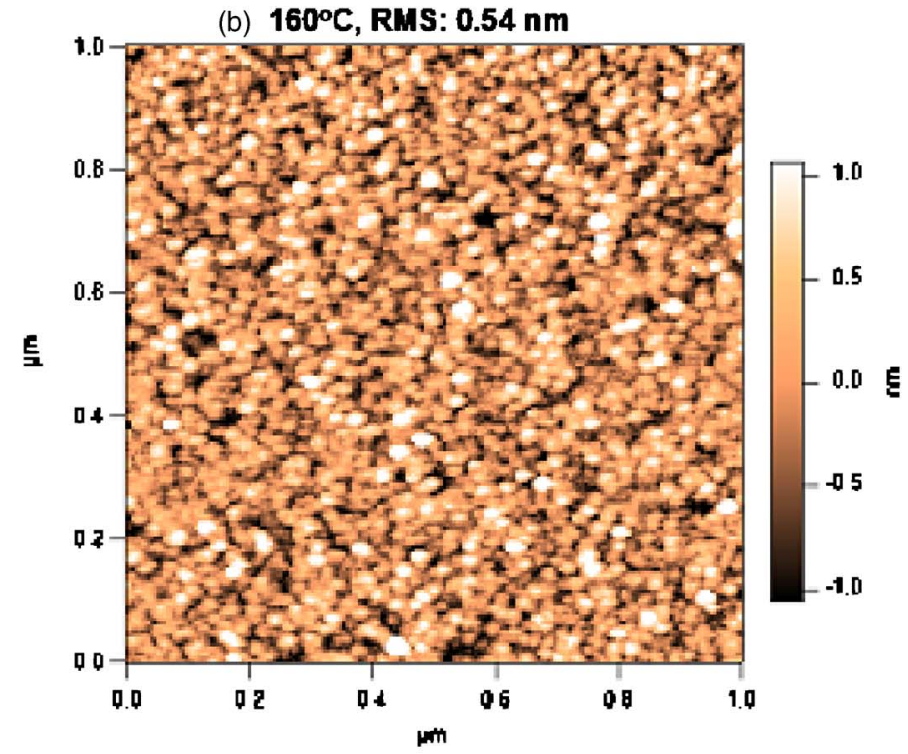

(d) $220^{\circ} \mathrm{C}$, RMS: $1.04 \mathrm{~nm}$

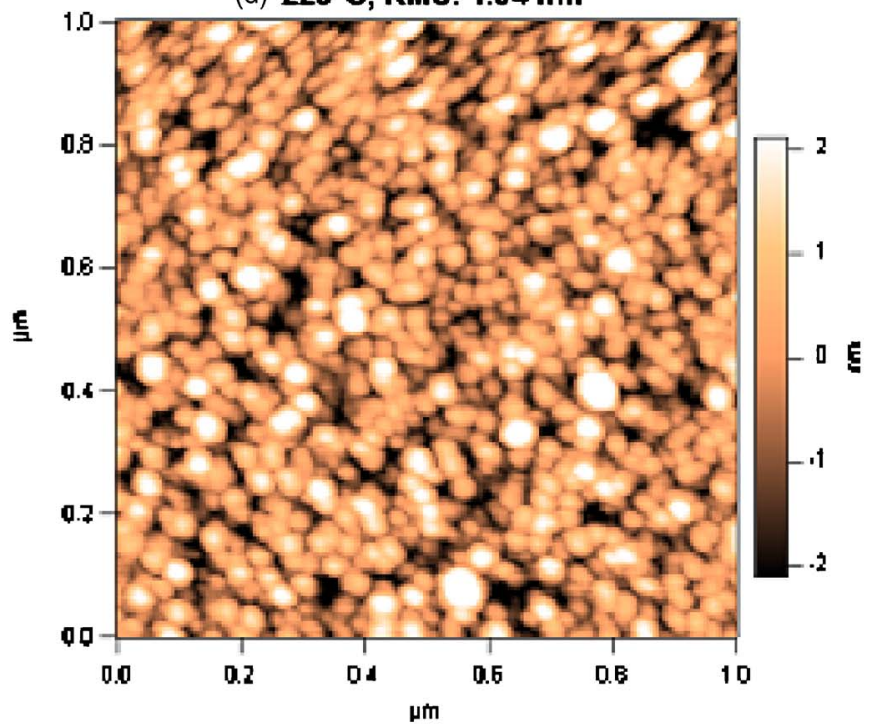

Figure 2. (Color online) AFM images of $\mathrm{CuON}$ films grown from $\left[\mathrm{Cu}\left({ }^{\mathrm{s}} \mathrm{Bu}-\mathrm{Me}-\mathrm{amd}\right)\right]_{2}$ vapor and a mixture of $30 \mathrm{sccm}$ of $\mathrm{H}_{2} \mathrm{O}$ and $10 \mathrm{sccm}$ of $\mathrm{NH}_{3}$ at (a) 140 , (b) 160 , (c) 180 , and (d) $220^{\circ} \mathrm{C}$, which have about $20 \mathrm{~nm}$ thickness.

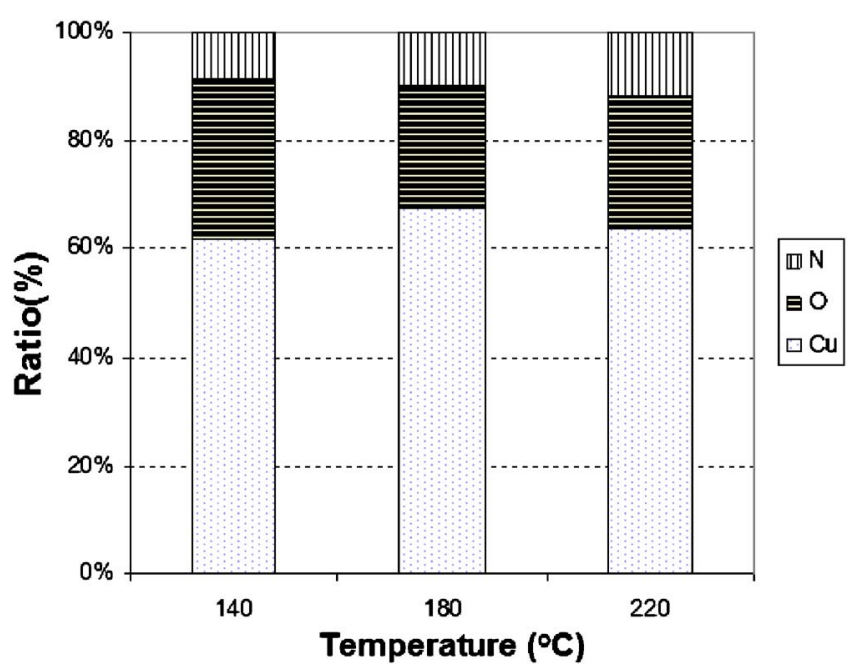

Figure 3. (Color online) The composition of $\mathrm{CuON}$ films deposited on carbon substrates from $\left[\mathrm{Cu}\left({ }^{\mathrm{S}} \mathrm{Bu}-\mathrm{Me}-\mathrm{amd}\right)\right]_{2}$ vapor and a mixture of $30 \mathrm{sccm}$ of $\mathrm{H}_{2} \mathrm{O}$ and $10 \mathrm{sccm}$ of $\mathrm{NH}_{3}$ at different temperatures, as measured by RBS.

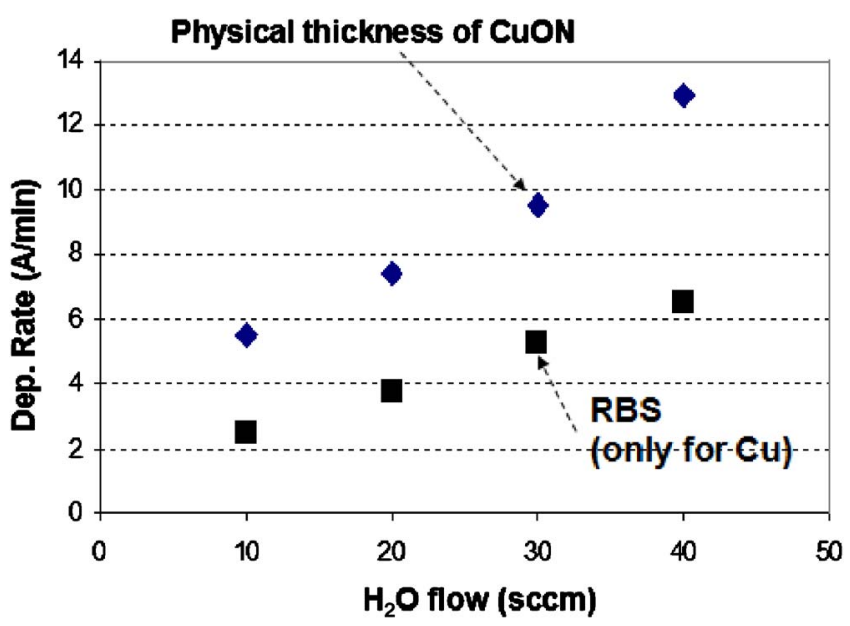

Figure 4. (Color online) Deposition rate of $\mathrm{CuON}$ film at different $\mathrm{H}_{2} \mathrm{O}$ and $\mathrm{NH}_{3}$ ratios at $140^{\circ} \mathrm{C}, 8$ Torr working pressure. Total flow rate of $\mathrm{H}_{2} \mathrm{O}$ and $\mathrm{NH}_{3}$ is maintained at $40 \mathrm{sccm}$. Thus, the $\mathrm{NH}_{3}$ flow rate is equal to $40 \mathrm{sccm}$ minus the $\mathrm{H}_{2} \mathrm{O}$ flow rate. 


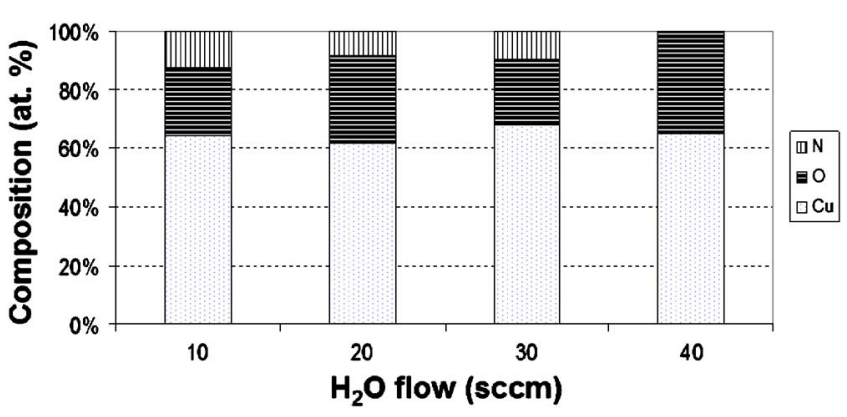

Figure 5. (Color online) Composition of $\mathrm{CuON}$ films deposited with different $\mathrm{H}_{2} \mathrm{O}$ to $\mathrm{NH}_{3}$ ratios at $140^{\circ} \mathrm{C}, 8$ Torr working pressure. The $\mathrm{NH}_{3}$ flow rate is equal to $40 \mathrm{sccm}$ minus the $\mathrm{H}_{2} \mathrm{O}$ flow rate. The composition was measured by RBS from films deposited on amorphous carbon substrates.

Compositions of $\mathrm{CuON}$ films deposited with different $\mathrm{H}_{2} \mathrm{O}$ to $\mathrm{NH}_{3}$ ratios at $140^{\circ} \mathrm{C}$ are shown in Fig. 5. The oxygen content of the films exceeds the nitrogen content, even for the film grown from an excess of ammonia $\left(\mathrm{H}_{2} \mathrm{O}\right.$ to $\mathrm{NH}_{3}$ flow ratio of 10:30). This is another indicator that water vapor is more reactive with the copper precursor than ammonia is. If we assign the conventional oxidation states to $\mathrm{O}(-2)$ and $\mathrm{N}(-3)$, these compositions all correspond closely to copper in the +1 oxidation state. Because the copper in the precursor is also in the +1 oxidation state, the reactions with $\mathrm{H}_{2} \mathrm{O}$ and $\mathrm{NH}_{3}$ do not produce any oxidation or reduction of the copper during CVD of the films.

The " $\mathrm{Cu}$ ratio" is defined by the ratio of $\mathrm{Cu}$ thickness to physical thickness of $\mathrm{CuON}$. The physical thickness of $\mathrm{CuON}$ film was measured by AFM after etching a stripe pattern. Cu thickness was measured by RBS and calculated as if it were pure copper with bulk density. From Fig. 6 the $\mathrm{Cu}$ ratio in the $\mathrm{CuON}$ films reached a maximum for the conditions of $30 \mathrm{sccm}$ of $\mathrm{H}_{2} \mathrm{O}$ and $10 \mathrm{sccm}$ of $\mathrm{NH}_{3}$. Films with a high $\mathrm{Cu}$ ratio contain more $\mathrm{Cu}$ that may be obtained by the reduction of a given thickness of $\mathrm{CuON}$.

All the $\mathrm{CuON}$ films have a very smooth surface morphology. The morphology of deposited $\mathrm{CuON}$ depends on the ratio of $\mathrm{H}_{2} \mathrm{O}$ to $\mathrm{NH}_{3}$ as shown in Fig. 7. With increasing the $\mathrm{H}_{2} \mathrm{O}$ ratio, the grain size increased, but the rms roughness value decreased, so the grains became wider, flatter, and less tall.

The crystal structure of $\mathrm{CuON}$ film depended on the ratio of flow rates of $\mathrm{H}_{2} \mathrm{O}$ to $\mathrm{NH}_{3}$. The structure was evaluated by electron diffraction in a TEM image (Fig. 8). The diffraction patterns were obtained from $\mathrm{CuON}$ films deposited in three different conditions: Fig. 8a for $10 \mathrm{sccm} \mathrm{H}_{2} \mathrm{O}$ and $30 \mathrm{sccm} \mathrm{NH}_{3}$, Fig. $8 \mathrm{~b}$ for $30 \mathrm{sccm}$ $\mathrm{H}_{2} \mathrm{O}$ and $10 \mathrm{sccm} \mathrm{NH} \mathrm{N}_{3}$, and Fig. $8 \mathrm{c}$ for $40 \mathrm{sccm} \mathrm{H}_{2} \mathrm{O}$. The electron diffraction pattern of Fig. 8a (high $\mathrm{NH}_{3}$ ) matches with the $\mathrm{Cu}_{3} \mathrm{~N}$ structure. $^{22}$ Those of Fig. $8 \mathrm{~b}$ and $\mathrm{c}\left(\right.$ high $\left.\mathrm{H}_{2} \mathrm{O}\right)$ coincide with the crystal structure of $\mathrm{Cu}_{2} \mathrm{O}^{23}$ The peak assignments are summarized in Tables I and II for the $\mathrm{Cu}_{3} \mathrm{~N}$ and $\mathrm{Cu}_{2} \mathrm{O}$ structures, respectively. Although the $\mathrm{CuON}$ films have similar compositions, the films show different crystal structures. The high ratio of $\mathrm{NH}_{3}$ only makes a $\mathrm{Cu}_{3} \mathrm{~N}$ structure, even though that film contains 24 atom \% oxygen. The high ratio of $\mathrm{H}_{2} \mathrm{O}$ makes $\mathrm{CuON}$ films having only the crystal structure of $\mathrm{Cu}_{2} \mathrm{O}$. We find no additional diffraction peaks that could arise from a crystalline mixed oxynitride phase, nor did we find any such phases reported. Thus, it seems likely that these films contain a significant amount of amorphous copper oxynitride that only has broad diffraction patterns and a smooth surface morphology.

It is thought that $\mathrm{H}_{2} \mathrm{O}$ reacts with the $\mathrm{Cu}$ precursor on a surface, followed by the reaction of $\mathrm{NH}_{3}$ with $\mathrm{Cu}-\mathrm{O}$ on the surface because $\mathrm{CuON}$ film is not deposited without $\mathrm{H}_{2} \mathrm{O}$. Thus, a high $\mathrm{NH}_{3}$ flow and low $\mathrm{H}_{2} \mathrm{O}$ flow make a low deposition rate of $\mathrm{Cu}_{2} \mathrm{O}$, causing a longer time for $\mathrm{NH}_{3}$ reaction on the surface, which results in the formation of $\mathrm{a} \mathrm{Cu}_{3} \mathrm{~N}$ structure containing oxygen. This result coincides with $\mathrm{ALD} \mathrm{Cu}_{3} \mathrm{~N}$ deposition using a pulse sequence of $\mathrm{Cu}$

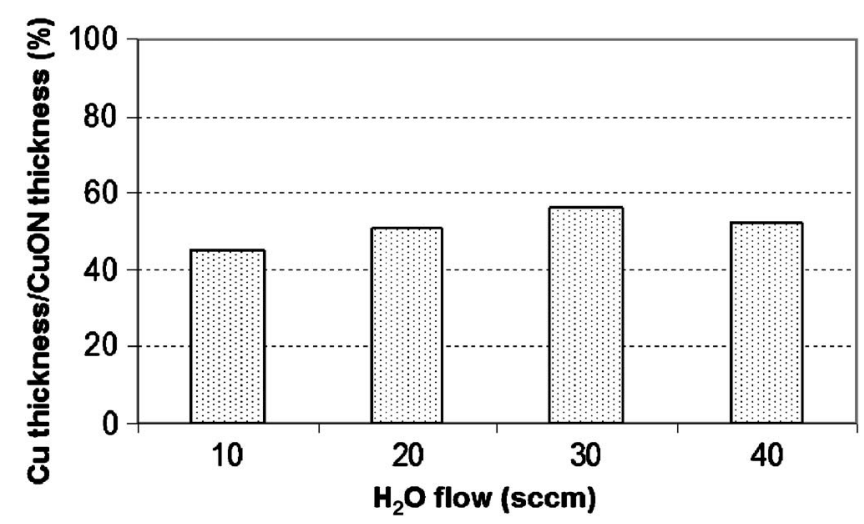

Figure 6. The ratio of $\mathrm{Cu}$ in the $\mathrm{CuON}$ film for different $\mathrm{H}_{2} \mathrm{O}$ and $\mathrm{NH}_{3}$ flow rates. The $\mathrm{Cu}$ ratio is defined by the ratio of $\mathrm{Cu}$ thickness (from $\mathrm{RBS}$ and calculated at the bulk density of $\mathrm{Cu}$ ) to physical thickness of $\mathrm{CuON}$.

precusor $/ \mathrm{H}_{2} \mathrm{O} / \mathrm{NH}_{3} .{ }^{16}$ Torndahl et al. ${ }^{16}$ made $\mathrm{Cu}$ oxide, first using $\mathrm{Cu}(\mathrm{hfac})_{2}$ and $\mathrm{H}_{2} \mathrm{O}$; then it was nitrified by a $\mathrm{NH}_{3}$ pulse, which resulted in the formation of $\mathrm{Cu}_{3} \mathrm{~N}$. Thus, $\mathrm{Cu}_{2} \mathrm{O}$ and $\mathrm{Cu}_{3} \mathrm{~N}$ can be formed by controlling the reaction gas ratio because the kinetic competition between $\mathrm{H}_{2} \mathrm{O}$ and $\mathrm{NH}_{3}$ with $\mathrm{Cu}$ atoms on the surface can make both structures.

The step coverage of CVD CuON was tested by depositing film on a silicon substrate with holes having aspect ratios of 40:1. The scanning electron microscopy (SEM) image of a cleaved cross section in Fig. 9 shows a step coverage of about $95 \%$ at the bottom of these very narrow holes.

Reduction of $\mathrm{CuON}$ with remote $\mathrm{H}_{2}$ plasma at room temperature.- $\mathrm{CuON}$ films can be deposited with different crystal structures and $\mathrm{Cu}$ densities depending on the ratio of $\mathrm{H}_{2} \mathrm{O}$ to $\mathrm{NH}_{3}$. The $\mathrm{CuON}$ film (high $\mathrm{H}_{2} \mathrm{O}$ CuON) with high $\mathrm{H}_{2} \mathrm{O}$ ratio $\left(\mathrm{H}_{2} \mathrm{O}: 30 \mathrm{sccm}, \mathrm{NH}_{3}: 10 \mathrm{sccm}\right)$ has a $\mathrm{Cu}_{2} \mathrm{O}$ crystal structure and a high $\mathrm{Cu}$ ratio (53\%). Low $\mathrm{H}_{2} \mathrm{O}$ CuON from low $\mathrm{H}_{2} \mathrm{O}$ ratio $\left(\mathrm{H}_{2} \mathrm{O}: 10 \mathrm{sccm}, \mathrm{NH}_{3}: 30 \mathrm{sccm}\right)$ has the crystal structure of $\mathrm{Cu}_{3} \mathrm{~N}$ and a low $\mathrm{Cu}$ ratio $(41 \%)$. Thus, these two films were used to compare the reduction behavior because these can represent high or low density films. High $\mathrm{H}_{2} \mathrm{O} \mathrm{CuON}$ has about a $12 \%$ higher $\mathrm{Cu}$ ratio than that of low $\mathrm{H}_{2} \mathrm{O} \mathrm{CuON}$.

The $\mathrm{CuON}$ films were reduced with remote $\mathrm{H}_{2}$ plasma. The films were not heated deliberately, but their temperature did rise from room temperature to about $50^{\circ} \mathrm{C}$ because of the heat released by the recombination of hydrogen atoms to form $\mathrm{H}_{2}$ and by reaction with oxygen and nitrogen on $\mathrm{CuON}$ surfaces. The as-deposited thicknesses of these high $\mathrm{H}_{2} \mathrm{O} \mathrm{CuON}$ and low $\mathrm{H}_{2} \mathrm{O}$ CuON films were 16 and $14 \mathrm{~nm}$, respectively. The sheet resistance of the films depends on reduction time as shown in Fig. 10. After 1 min reduction treatment, both $\mathrm{CuON}$ films were reduced to $\mathrm{Cu}$. The sheet resistance is not changed further after 3 min reduction, which means that reduction for $1 \mathrm{~min}$ is sufficient to reduce $14-16 \mathrm{~nm}$ thick $\mathrm{CuON}$ films with either crystal structure. The morphology of reduced $\mathrm{CuON}$ was evaluated by AFM, shown in Fig. 11. Both high $\mathrm{H}_{2} \mathrm{O}$ and low $\mathrm{H}_{2} \mathrm{O}$ $\mathrm{CuON}$ a showed smooth surface morphology $(1.1-1.2 \mathrm{~nm} \mathrm{rms}$ roughness) even after 3 min reduction. Thus, the reduced $\mathrm{Cu}$ films were not agglomerated even at a longer reduction time. Because the films retain their smooth morphology even after over-reduction for longer times, we expect that films can also be reduced successfully inside the whole length of deep trenches. Film near the top of a trench will be reduced before film deeper in the trench, which only receives a smaller flux of hydrogen atoms depleted by reactions at the walls during their diffusion down the trench.

Because these films were reduced at nearly room temperature, they can maintain their smooth surface morphology by avoiding diffusion of the $\mathrm{Cu}$ over the $\mathrm{Ru}$ surface to form agglomerates. How- 

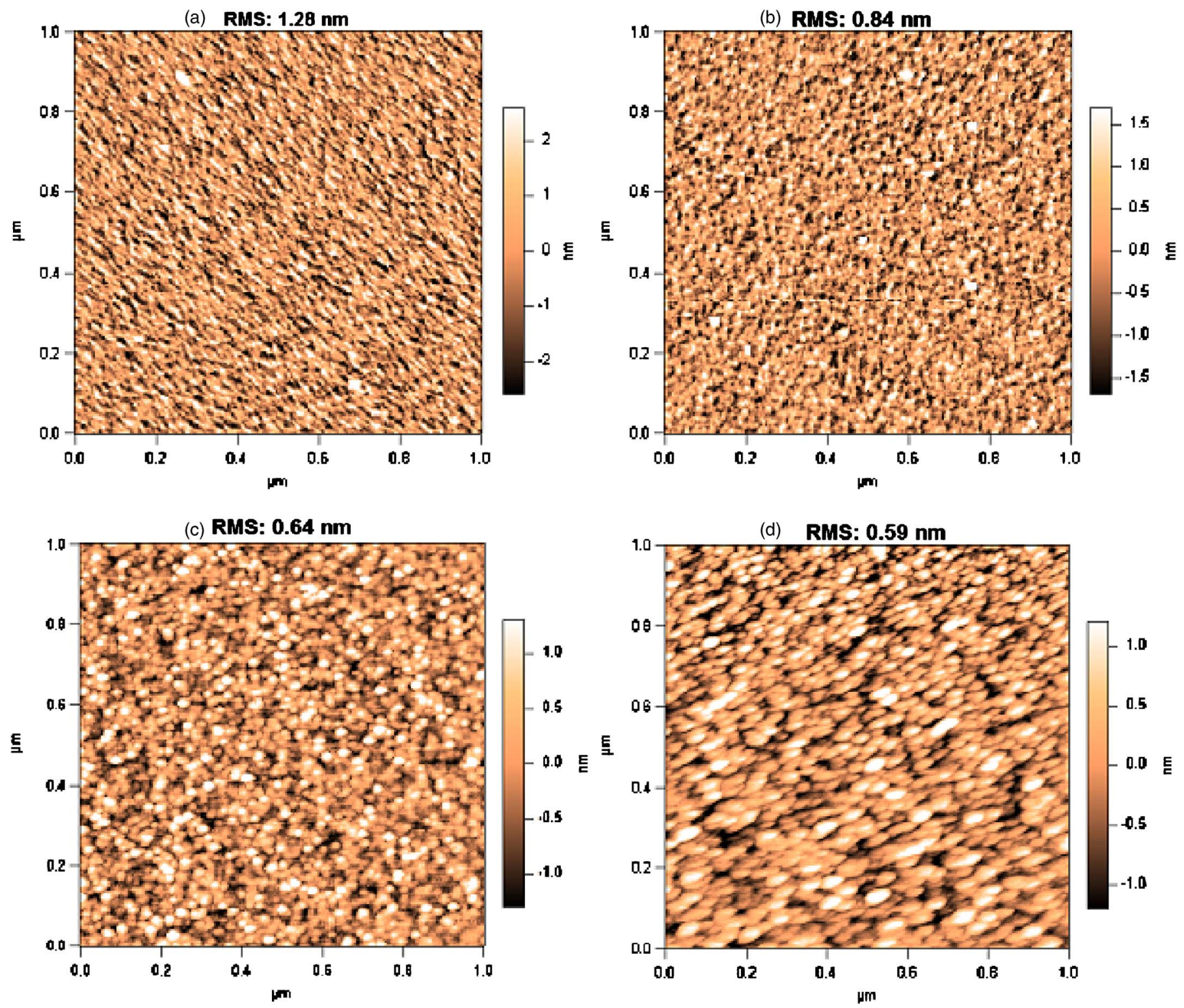

Figure 7. (Color online) AFM image of $\mathrm{CuON}$ film grown at $140{ }^{\circ} \mathrm{C}$ with the flow rate of $\mathrm{H}_{2} \mathrm{O}$ and $\mathrm{NH}_{3}$; (a) 10:30, (b) 20:20, (c) 30:10, and (d) 40:0 sccm.

ever, $\mathrm{CuON}$ films deposited on $\mathrm{SiO}_{2}$ underlayers were agglomerated under the same reduction condition, as shown by the increase in rms roughness from 0.7 to $\sim 3.5 \mathrm{~nm}$ (Fig. 12). Any surface oxide on ruthenium can be reduced during the $\mathrm{CuON}$ reduction because the stabilities of $\mathrm{Cu}_{2} \mathrm{O}$ and $\mathrm{RuO}_{2}$ are similar. The Gibbs energies of the reduction reactions for these oxides are similar, ${ }^{21}$ which implies both metal oxides can be reduced under similar reduction conditions. The $\mathrm{Cu}$ is bonded strongly to the reduced metallic surface of Ru. However, $\mathrm{Cu}$ on $\mathrm{Si}$ having a native oxide can be agglomerated during reduction even at room temperature due to the high mobility of $\mathrm{Cu}$ atoms on oxide surfaces ${ }^{9}$ and the difficulty of reducing silicon oxides. Thus, an easily reducible underlayer like $\mathrm{Ru}$ is essential for maintaining a smooth surface morphology during the reduction of CuON.

The volume shrinkage of two $\mathrm{CuON}$ films was evaluated by comparing the thickness of $\mathrm{CuON}$ film before and after reduction. The physical thickness of high $\mathrm{H}_{2} \mathrm{O} \mathrm{CuON}$ is changed from 16 to 9 $\mathrm{nm}$, which is a shrinkage of volume by $45 \%$. Low $\mathrm{H}_{2} \mathrm{O} \mathrm{CuON}$ showed that the thickness is changed from 14 to $7 \mathrm{~nm}$, which means a $50 \%$ volume shrinkage. These samples are evaluated by RBS to measure the density of reduced $\mathrm{Cu}$ film. The RBS result shows that the thickness of high or low $\mathrm{H}_{2} \mathrm{O} \mathrm{CuON}$ would be 8.5 or $5.9 \mathrm{~nm}$, respectively, if they had bulk $\mathrm{Cu}$ density. Thus, comparing these values with the physical thicknesses, the density of the reduced copper from high $\mathrm{Cu}_{2} \mathrm{O} \mathrm{CuON}$ or low $\mathrm{H}_{2} \mathrm{O} \mathrm{CuON}$ is 95 or $84 \%$, respectively, of the bulk value. Summarizing the density of the $\mathrm{CuON}$ films, high $\mathrm{Cu}_{2} \mathrm{O} \mathrm{CuON}$ has a higher density not only in the asdeposited film but also after reduction. Thus, high $\mathrm{Cu}_{2} \mathrm{O} \mathrm{CuON}$ film should be used as the most suitable $\mathrm{Cu}$ compound for reduction to deposit a dense, reduced $\mathrm{Cu}$ film.

The resistivity of reduced high $\mathrm{Cu}_{2} \mathrm{O} \mathrm{CuON}$ is $12 \mu \Omega \mathrm{cm}$ at a thickness of $9 \mathrm{~nm}$. That of low $\mathrm{H}_{2} \mathrm{O} \mathrm{CuON}$ film has $15 \mu \Omega \mathrm{cm}$ at a thickness of $7 \mathrm{~nm}$. These values are similar to the resistivity of sputtered $\mathrm{Cu}$ at the corresponding thicknesses. ${ }^{15}$ Thus, the reduced $\mathrm{Cu}$ film has a high density and high purity.

All the reduced copper films on ruthenium pass the tape test for adhesion, whereas the ones on silica are easily pulled off by tape. More quantitative 4-point bend tests of adhesion are underway.

\section{Conclusions}

Smooth, continuous, dense, and conformal $\mathrm{Cu}$ films with $\sim 1 \mathrm{~nm}$ rms roughness and thickness $<10 \mathrm{~nm}$ were fabricated by 


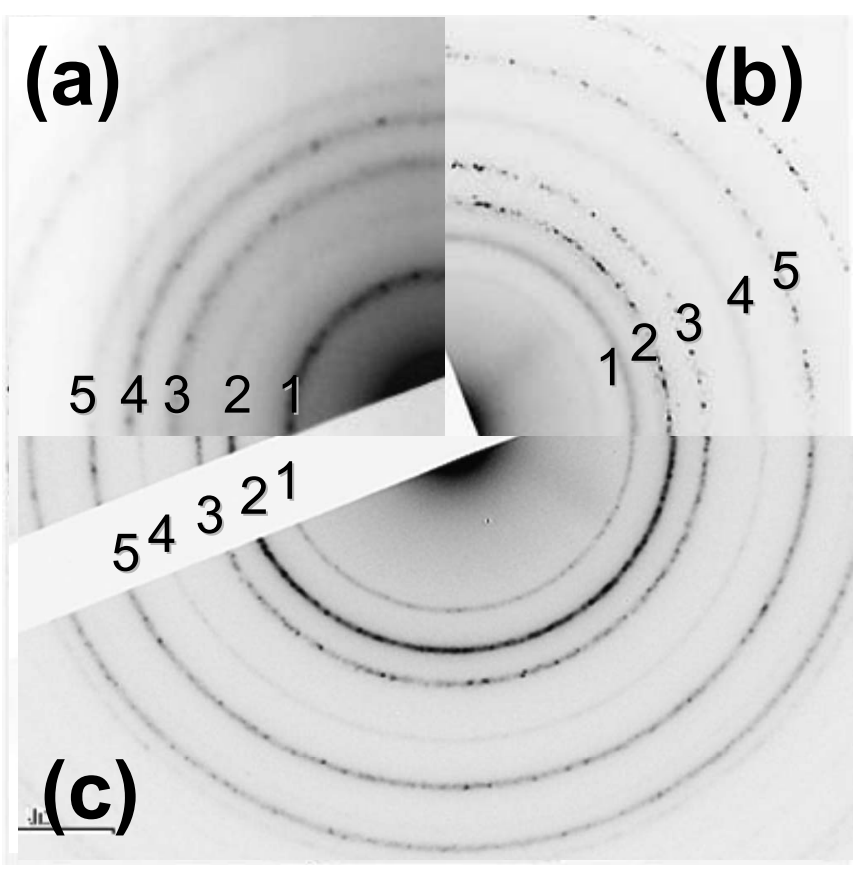

Figure 8. TEM diffraction pattern of $\mathrm{CuON}$ films grown at $140^{\circ} \mathrm{C}$ with the flow rate of $\mathrm{H}_{2} \mathrm{O}$ and $\mathrm{NH}_{3}$ at (a) 10:30, (b) 30:10, and (c) 40:0 sccm.

$\mathrm{CVD}$ of $\mathrm{CuON}$ followed by reduction with remote hydrogen plasma at room temperature. The crystal structure of $\mathrm{CuON}$ can be controlled by the ratio of $\mathrm{H}_{2} \mathrm{O}$ and $\mathrm{NH}_{3}$, although the elemental composition of the film was not changed significantly. A high $\mathrm{H}_{2} \mathrm{O}$ ratio makes the $\mathrm{CuON}$ film having a $\mathrm{Cu}_{2} \mathrm{O}$ crystal structure. A low $\mathrm{H}_{2} \mathrm{O}$ ratio, meaning high $\mathrm{NH}_{3}$ partial pressure, makes $\mathrm{CuON}$ films having a $\mathrm{Cu}_{3} \mathrm{~N}$ crystal structure. The reduction rate of the films does not show any difference depending on the crystal structure. $\mathrm{CuON}$ film with a $\mathrm{Cu}_{2} \mathrm{O}$ structure produces a higher density of $\mathrm{Cu}$ after reduction. Thus, $\mathrm{CuON}$ having a $\mathrm{Cu}_{2} \mathrm{O}$ structure is the best $\mathrm{Cu}$ compound

\begin{tabular}{|c|c|c|c|c|c|}
\hline No. & $h k l$ & $d(\mathrm{~A})$ & Int. & $\begin{array}{c}\text { Measured } \\
d(\mathrm{~A})\end{array}$ & $\begin{array}{c}\text { Error } \\
(\%)\end{array}$ \\
\hline 1 & 100 & 3.82 & 60 & 3.83 & -0.26 \\
\hline 2 & 110 & 2.70 & 30 & 2.69 & 0.21 \\
\hline 3 & 111 & 2.20 & 100 & 2.20 & -0.02 \\
\hline 4 & 200 & 1.91 & 80 & 1.91 & -0.29 \\
\hline 5 & 210 & 1.71 & 30 & 1.69 & 0.89 \\
\hline
\end{tabular}

\begin{tabular}{|c|c|c|c|c|c|}
\hline No. & $h k l$ & $d(\mathrm{~A})$ & Int. & $\begin{array}{c}\text { Measured } \\
d(\mathrm{~A})\end{array}$ & $\begin{array}{c}\text { Error } \\
(\%)\end{array}$ \\
\hline 1 & 110 & 3.04 & 20 & 3.03 & 0.32 \\
\hline 2 & 111 & 2.46 & 100 & 2.46 & 0.04 \\
\hline 3 & 200 & 2.14 & 70 & 2.14 & -0.13 \\
\hline 4 & 211 & 1.74 & 20 & 1.74 & -0.24 \\
\hline 5 & 220 & 1.51 & 90 & 1.50 & 0.66 \\
\hline
\end{tabular}

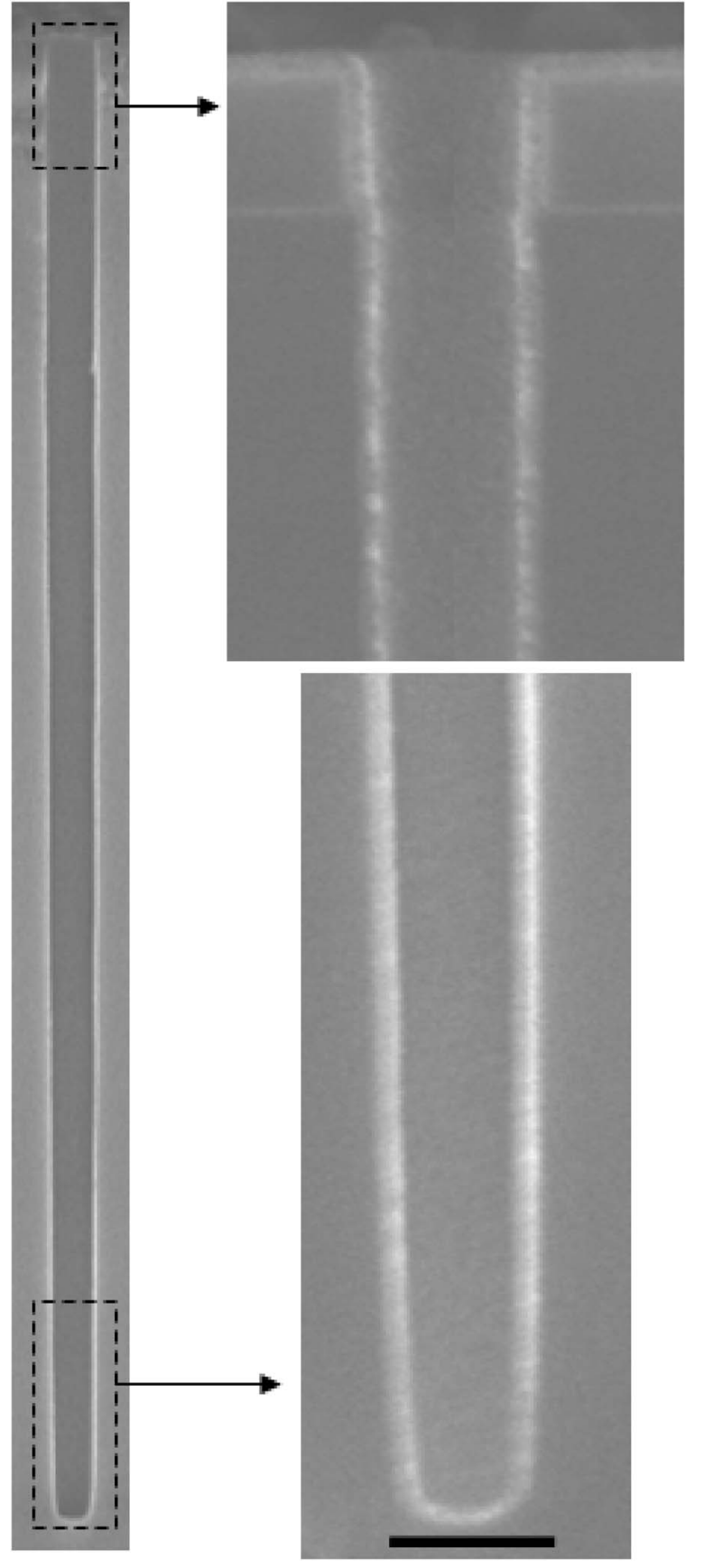

Figure 9. SEM image of a $\mathrm{CuON}$ film deposited at $140^{\circ} \mathrm{C}$ with $30 \mathrm{sccm}$ of $\mathrm{H}_{2} \mathrm{O}$ and $10 \mathrm{sccm}$ of $\mathrm{NH}_{3}$ on an oval hole (diameter 0.13 $\times 0.19 \mu \mathrm{m}$, length $6.7 \mu \mathrm{m})$. Scale bar is $200 \mathrm{~nm}$.

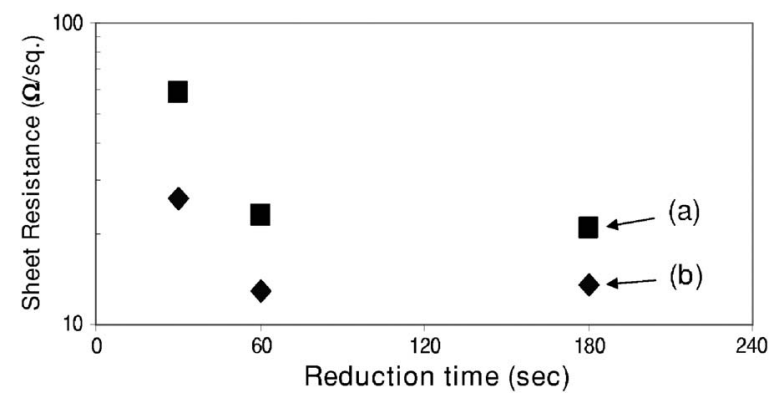

Figure 10. Sheet resistance of (a) low and (b) high $\mathrm{H}_{2} \mathrm{O} \mathrm{CuON}$ film depending on reduction time at room temperature. 

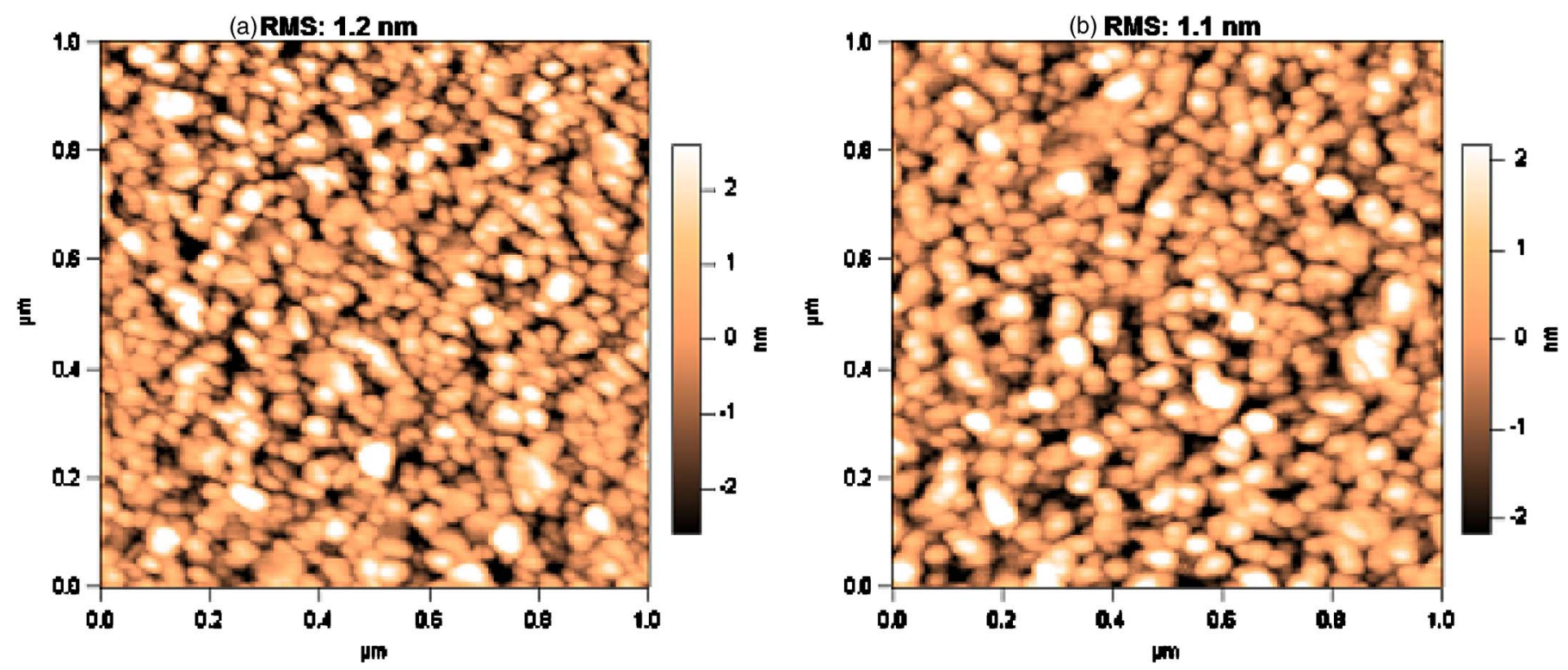

Figure 11. (Color online) AFM image of reduced $\mathrm{Cu}$ films from (a) low and (b) high $\mathrm{H}_{2} \mathrm{O}$ CuON at room temperature for 3 min on Ru substrates.
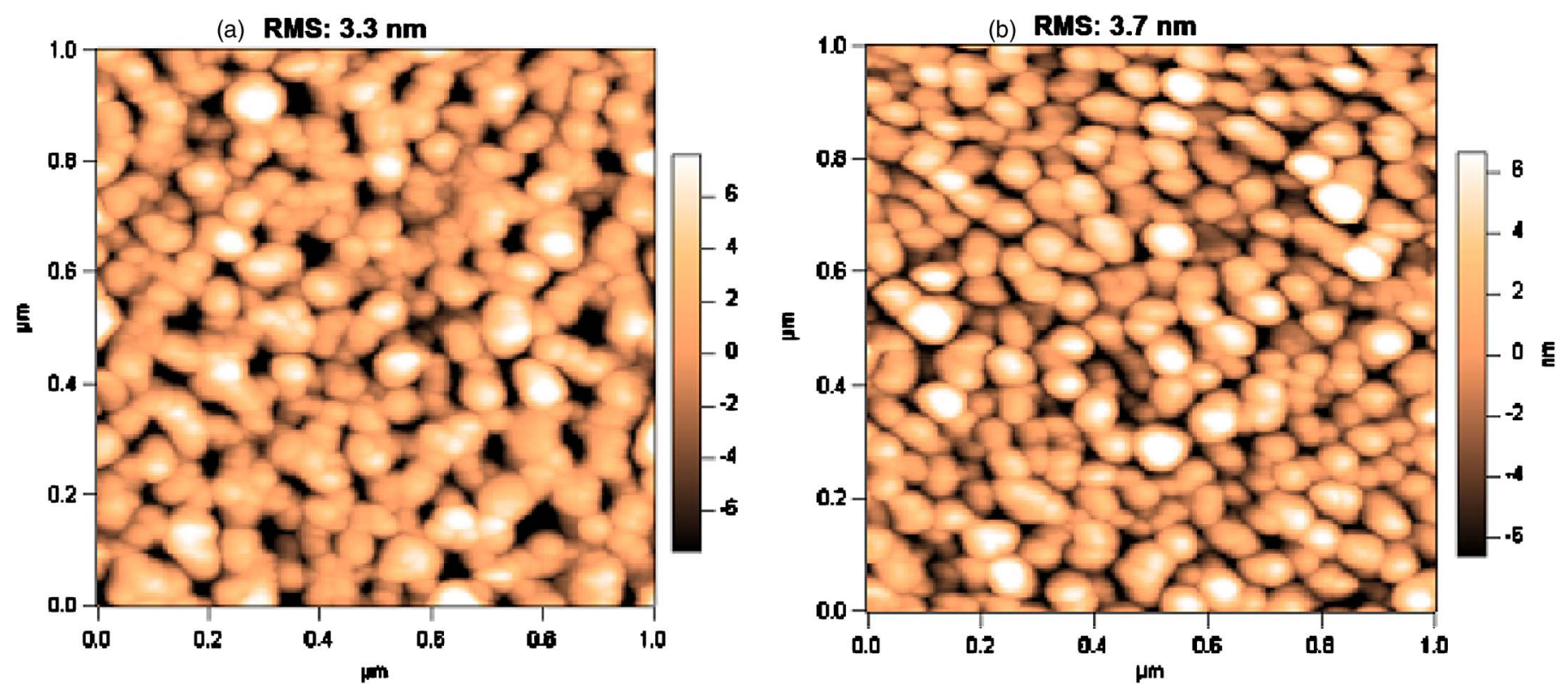

Figure 12. (Color online) AFM image of reduced $\mathrm{Cu}$ films from (a) low and (b) high $\mathrm{H}_{2} \mathrm{O}$ CuON at room temperature for 3 min on $\mathrm{SiO}_{2}$ substrates.

for this deposition and reduction process, which is a promising method for $\mathrm{Cu}$ seed layer deposition for future $\mathrm{Cu}$ interconnects.

\section{Acknowledgments}

The copper precursor was supplied by the Advanced Thin-Film Technologies Group, Rohm and Haas Electronic Materials. Silicon substrates with deep trenches were supplied by Qimonda. Support for this work was provided by the Rohm and Haas Company, Intel Corporation, and the National Science Foundation.

Harvard University assisted in meeting the publication costs of this article.

\section{References}

1. R. Rosenberg, D. C. Edelstein, C.-K. Hu, and K. P. Rodbell, Annu. Rev. Mater. Sci., 30, 229 (2000)

2. A. H. Simon, S. B. Law, J. B. Tan, S. G. Malhotra, K. S. Lam, S.-C. Seo, and P.

Dehaven, in Proceedings of Adv. Met. Conference, Materials Research Society, p.
$545(2004)$

3. R. Kroger, M. Eizenberg, D. Cong, N. Yoshida, L. Y. Chen, S. Ramaswami, and D. Carl, J. Electrochem. Soc., 146, 3248 (1999).

4. Y. S. Kim and Y. Shimogaki, J. Vac. Sci. Technol. A, 19, 2642 (2001).

5. H. Kim and Y Shimogaki, J. Electrochem. Soc., 154, G13 (2007).

6. O. K. Kwon, J. H. Kim, H. S. Park, and S. W. Kang, J. Electrochem. Soc., 151, G109 (2004)

7. H. Kim, Y. Kojima, H. Sato, N. Yoshii, S. Hosaka, and Y. Shimogaki, Jpn. J. Appl. Phys., Part 2, 45, L233 (2006).

8. R. Solanki and B. Pathangey, Electrochem. Solid-State Lett., 3, 479 (2000).

9. Z. Li, A. Rahtu, and R. G. Gordon, J. Electrochem. Soc, 153, C787 (2006).

10. Semiconductor Industry Association, International Technology Roadmap for Semiconductors, 2007 ed., SEMATECH, Austin, TX (2007).

11. P. R. Subramanian, D. J. Chakrabarti, and D. E. Laughlin, Phase Diagrams of Binary Copper Alloys, p. 412, ASM International, Materials Park, OH (1994).

12. H. Kim, T. Koseki, T. Ohba, T. Ohta, Y. Kojima, H. Sato, and Y. Shimogaki, $J$. Electrochem. Soc., 152, G594 (2005).

13. H. Kim, Y. Naito T. Koseki, T. Ohba, T. Ohta, Y. Kojima, H. Sato, and Y. Shimogaki, Jpn. J. Appl. Phys., 45, 2497 (2006).

14. C. Lee and H.-H. Lee, Electrochem Solid-State Lett, 8, G5 (2005).

15. Z. Li and R. G. Gordon, Chem. Vap. Deposition, 12, 435 (2006). 
16. T. Torndahl, M. Ottosson, and J. Carlsson, J. Electrochem. Soc., 153, C146 (2006).

17. J. Pinkas, J. C. Huffman, D. V. Baxter, M. H. Chisholm, and K. G. Caulton, Chem. Mater., 7, 1589 (1995).

18. P. J. Soininen, K.-E. Elers, V. Saanila, S. Kaipio, T. Sajavaara, and S. Haukka, J. Electrochem. Soc., 152, G122 (2005).

19. H. Kim, Y. Kojima, H. Sato, N. Yoshii, S. Hosaka, and Y. Shimogaki, in Proceedings of Materials Research Society Spring Meeting 2006, Materials Research Society, p. 0914-F05-115 (2006).
20. Y. Sawada, H. Tamaru, M. Kogoma, M. Kawase, and K. Hashimoto, J. Phys. D, 29, 2539 (1996).

21. D. R. Lide, CRC Handbook of Chemistry and Physics, 76th ed., p. 1995, CRC Press, Boca Raton, FL (1995-1996).

22. U. Zachwieja and H. Jaconbs, J. Less-Common Met., 161, 175 (1990).

23. R. Restori and D. Schwarzenbach, Acta Crystallogr., Sect. B: Struct. Sci., B42, 201 (1986). 